\title{
Molluscan and Vertebrate Successions from the Vel'ká Drienčanská Cave
}

\author{
Vojen Ložek (with the contribution of Ján Darola, Vertebrata) \\ Institute of Geology AV ČR, v. v. i., Rozvojová 269, 16500 Praha 6
}

\begin{abstract}
LožEK V., 2012: Molluscan and Vertebrate Successions from the Vel'ká Drienčanská Cave. - Malacologica Bohemoslovaca, 11: 39-44. Online serial at $<$ http://mollusca.sav.sk> 7-Oct-2012.

Here we present a biostratigraphy of entrance deposits in the Vel'ká Drienčanská Cave based on molluscan and vertebrate successions in correlation with prehistoric pottery records. This corresponds to the final Last Glacial - Holocene time-span and reflects the following environmental history: the coexistence of open-country and woodland snail communities throughout the whole succession documents the persistence of high-diversity karsts parkland since the Late Glacial up to present, which has been supported by human activities since the Neolithic occupation. However, the molluscan succession shows a general agreement with the standard mid-European developmental pattern. The molluscan evidence is confirmed by vertebrate fossil finds.
\end{abstract}

Key words: Central Slovakia, West Carpathians, cave-entrance fill, molluscan succession, vertebrates, Late Glacial, Holocene, karstland

\section{Introduction}

The Great Drienčanská Cave (Vel'ká Drienčanská jaskyňa) is situated in the Drienčanský Karst, a small isolated karstland area in the western vicinity of the Slovak Karst. The cave has been described by several speleologists (KLiment ed., 2000) as well as by the archaeologist Juraj BÁRTA (1963) who published a short report on his find of Late Bronze Age pottery from a shallow test pit in the cave fill. The first molluscan and vertebrate records came from an excavation situated at the cave entrance started in 1976 and continued in 1981 which was undertaken in cooperation with the State Nature Conservancy of the Slovak Republic.

This investigation was carried out within the framework of a comprehensive study of the terrestrial-carbonate facies of the mid-European Holocene and Late Pleistocene (LOžEK $\&$ Cí́teK 2003). The aim was to collect a sufficient number of fossils for a detailed analysis of its development within the south-eastern West-Carpathian foothill area, where glacial refugees of a number of climatically demanding mid-European snail and mammal species might be expected (LožEK 2006).

The main problems that are to be elucidated are the following:

- Local successions of snail and vertebrate assemblages.

- Variations in climate indicated by molluscs, mammals and sediments.

- Survival of Carpathian endemics and further moderateclimate species during the glacial.

- Reconstruction of local paleoenvironments in comparison with the standard developmental pattern of Central Europe.

\section{Site description}

The Vel'ká Drienčanská Cave is located at the southwestern edge of the Drienčanský Karst Area in the eastern side of the shallow valley of the stream Blh. Its smalltunnel shaped entrance lies in a steep slope consisting of Upper Triassic limestone $18 \mathrm{~m}$ above the floodplain.

Basic geographic and climatic data are:

Latitude: $48^{\circ} 29^{\prime} 23^{\prime \prime} \mathrm{N}$

Longitude: $20^{\circ} 03^{\prime} 45^{\prime \prime} \mathrm{E}$

Altitude: $246 \mathrm{~m}$

Mean annual rainfall: $631 \mathrm{~mm}$

Mean annual temperature: $8,5^{\circ} \mathrm{C}$

Mean July temperature: $19.7^{\circ} \mathrm{C}$

Mean January temperature: $-4.0^{\circ} \mathrm{C}$

Vegetation period m.t.: $15.7^{\circ} \mathrm{C}$

The wide surroundings of the cave are covered by xerothermophilous scrubland with a patchwork of scrubtrees and steppe grasslands representing since prehistoric times a typical pastureland at the boundary of the preCarpathian region and the Primordial Matricum district of the Pannonian region, which is considered to have been a refuge for many demanding plants and animals during the glacial phases. The primeval vegetation cover was dominated by thermophilous oak and oak-hornbeam woodland with local patches of beech stands including a reduced number of submontane elements.

\section{The stratigraphic sequence}

The excavation pit was located at the SE-margin of the entrance, mostly out of the cave entrance. In the absence of any indications of the activity of running water within the depositional sequence, the entirely predominating 
source of the sedimentary fill has been the breakup of the surrounding bedrock as well as soil material from the slope. The uppermost part may also include debris introduced by human inhabitants. Windblown material and loose $\mathrm{CaCO}_{3}$ precipitations from dripping water and moistened rock walls are nearly absent.

\section{Methods}

The depositional sequence was cleaned, described (Fig. 1) and $9 \mathrm{dm}^{3}$ samples were taken in open section from all macroscopically distinguishable layers. The thickest layer 6 was subdivided into two sublayers $(6 a, 6 b)$.

Molluscs and vertebrate bones were extracted from the sediments by wet sieving. After drying, each sample was disintegrated in water, partly with the aid of $30 \%$ hydrogen peroxide $\left(\mathrm{H}_{2} \mathrm{O}_{2}\right)$. Floating shells were decanted into a $0.5 \mathrm{~mm}$ sieve. The residual sediment was then wet-sieved, to remove all material $<0.4 \mathrm{~mm}$, before being dried. The shells and their fragments as well as small bones and teeth were picked using fine pincers. Complete molluscan faunas from particular layers were counted and scored using the standard techniques described in detail in LožEK (1964). Results are given in Tables 1 and 2; Table 1 also contains basic information on the chronostratigraphic and paleoenvironmental significance of particular molluscan species. A graphical presentation has been omitted since mollusc abundances vary greatly throughout the sequence and important changes in molluscan fauna should be clear from Table 1.

\section{Molluscan succession}

The basal horizons of the sedimentary sequence (13-9) are virtually barren, including only a few very small indeterminable fragments whereas the uppermost humic strata yielded rich material. Consequently, a mollusc diagram plotting the fauna data as percentages would be misleading. Results of the molluscan analyses are therefore presented only in numbers of individuals in Table 1.

The overall impression from the lowest part of the succession (8-7) is of severe conditions, indicated by the presence of species-poor assemblages dominated by the thermotolerant petrophilous Clausilia dubia. Throughout the interval $6 \mathrm{~b}-5$ the fauna becomes enriched first in catholic, later also in a few more demanding taxa (5), indicating the onset of woodland expansion and warming (Truncatellina cylindrica, Euomphalia strigella, Aegopinella minor, Fruticicola fruticum, as well as Granaria and Chondrula), which is indicative of the Late Glacial-Early Holocene time-span.

Subsequent forest optimum faunas that culminate only in subsurface layer 2 are characterized by species with higher moisture and shade requirements such as Cochlodina orthostoma, Daudebardia rufa, Oxychilus glaber, Discus perspectivus, Petasina unidentata, Vitrea diaphana or Helix pomatia. Local deciduous forest-optimum conditions

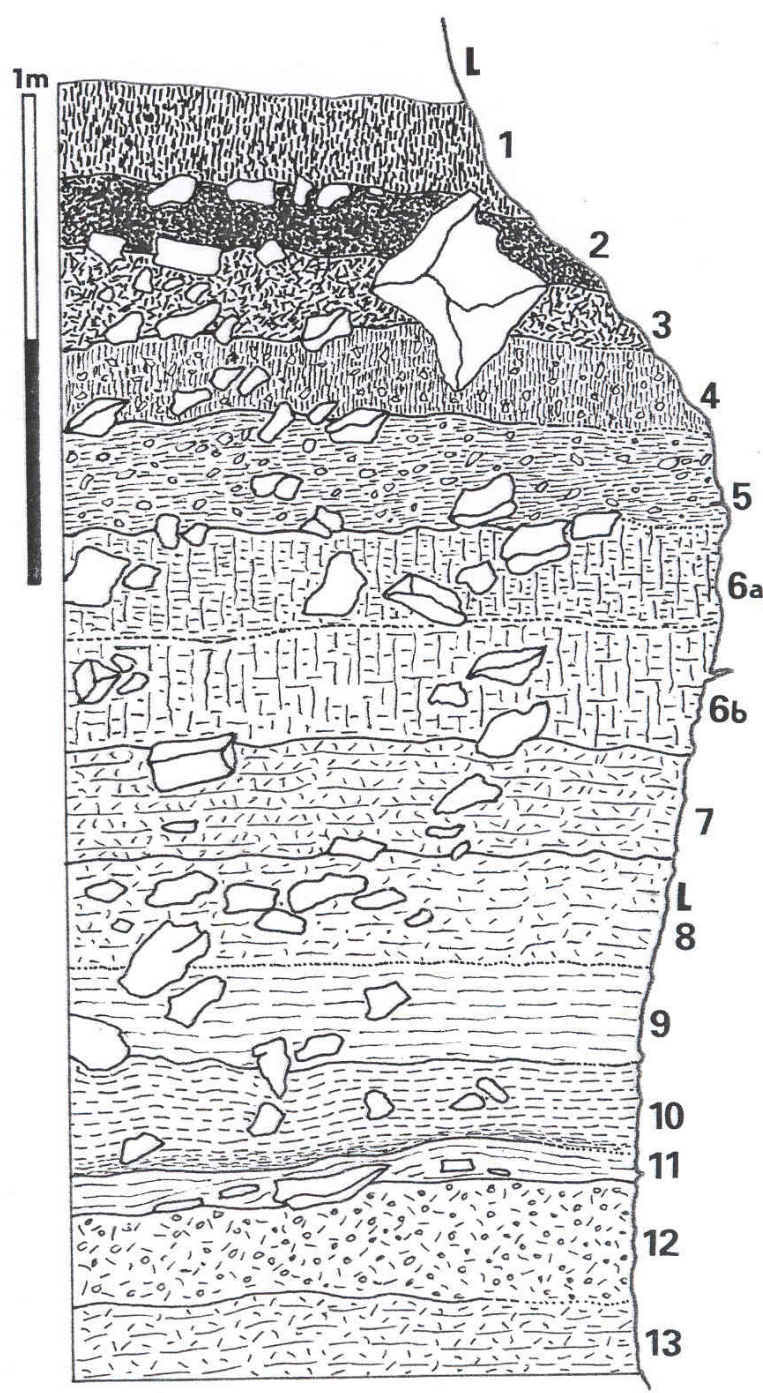

Fig. 1. Lithology of the stratigraphic sequence in the cave entrance:

1 - very dark grey humic loam with poorly developed fine crumb structure, 2 - very dark grey humus-rich loam, fine crumb structure, scattered fine-grained rock rubble, 3 - very dark brown humic loam with crumb structure, rather low in fine rubble, 4 - dark brown slightly humic loam with crumb structure, rather rich in small-sized rubble, 5 - greyish ochreous loam, rather rich in fine rubble, $6 \mathrm{a}$ - greyish ochreous loam, rock rubble in small amounts, $6 \mathrm{~b}$ - paler greyish ochreous loam, rock rubble in small amounts, 7 - greyish ochreous loam with abundant rubble, 8 - pale greyish brown loam with abundant rubble, 9 - strong brown moderately clayey loam with dark basal zone, moderately rounded stones, 10 - chocolate brown moderately clayey loam with very dark basal zone, moderately rounded stones, 11 - light beige clay with flat lying stones, 12 - greyish beige clayey loam with abundant rubble, 13 - darker beige clayey loam with abundant rubble.

(Large stones are plotted in the picture.)

Table 1. Ecogroups: 1 - closed forest; 2 - woodland, occasionally open habitats; 3 - moist woodland, floodplain forest; 4 - steppe, xerothermic rocks; 5 - open habitat in general; woodland and open groups: 6 - predominantly dry; 7 - mesic; 10 - aquatic habitats. Malacostratigraphic indexes: ! - warm phases (interglacial, Holocene), !! - Interglacial index species, (!) - euryoecic thermophiles, +- loess species, $(+)$ - occasional or local loess species, $G$ - surviving the glacials out of the loess zone, $(G)-$ as relics. 


\begin{tabular}{|c|c|c|c|c|c|c|c|c|c|c|c|}
\hline \multirow{2}{*}{\multicolumn{2}{|c|}{$\begin{array}{l}\text { Ecogroups Biostrati- } \\
\text { graphic indexes }\end{array}$}} & \multirow{3}{*}{$\begin{array}{l}\text { Mollusca } \\
\text { Acanthinula aculeata (O.F. Müller, 1774) }\end{array}$} & \multicolumn{9}{|c|}{ Layers } \\
\hline & & & \multirow{2}{*}{8} & \multirow[t]{2}{*}{7} & \multirow{2}{*}{$6 \mathrm{~b}$} & \multirow{2}{*}{$6 \mathrm{a}$} & \multirow[t]{2}{*}{5} & \multirow[t]{2}{*}{4} & \multirow{2}{*}{3} & \multirow{2}{*}{$\frac{2}{2}$} & \multirow{2}{*}{$\frac{1}{1}$} \\
\hline \multirow{13}{*}{1} & $!$ & & & & & & & & & & \\
\hline & $!$ & Cochlodina orthostoma (Menke, 1828) & & & & & 1 & & 1 & 9 & 1 \\
\hline & $!$ & Daudebardia rufa (Draparnaud, 1805) & & & & & & & 1 & 2 & 3 \\
\hline & $! !$ & Discus perspectivus (M. von Mühlfeld, 1816) & & & & & & & & 1 & \\
\hline & (G) & Discus ruderatus (A. Férussac, 1821) & & & & & & 1 & & 1 & \\
\hline & $(!)$ & Faustina faustina (Rossmässler, 1835) & $1 ?$ & & & 1 & 2 & 2 & 5 & 12 & 6 \\
\hline & $!$ & Helicodonta obvoluta (O.F. Müller, 1774) & & & & & & & & $1 ?$ & 1 \\
\hline & $!$ & Isognomostoma isognomostomos (Schröter, 1784) & & & & & & & $1 ?$ & 2 & 1 \\
\hline & $!$ & Macrogastra plicatula (Draparnaud, 1801) & & & & & & $1 ?$ & & 1 & \\
\hline & $!$ & Monachoides incarnatus (O.F. Müller, 1774) & & & & & & & & 3 & 1 \\
\hline & $!$ & Petasina unidentata (Draparnaud, 1805) & & & $1 ?$ & $1 ?$ & & & 2 & 3 & \\
\hline & $!$ & Vitrea diaphana (Studer, 1820$)$ & & & & 1 & & 3 & 5 & 11 & 6 \\
\hline & $!$ & Vitrea cf. subrimata (Reinhardt, 1871) & & & & & & 1 & & & \\
\hline \multirow{9}{*}{2} & $!$ & Alinda biplicata (Montagu, 1803) & & & & & & $1 ?$ & 5 & 17 & 45 \\
\hline & $!$ & Discus rotundatus (O.F. Müller, 1774) & & & & & & & 2 & & \\
\hline & $?$ & Limax cf. cinereoniger Wolf, 1803 & & & & & 1 & & & & \\
\hline & $!$ & Oxychilus glaber (Rossmässler, 1835) & & & & & $2 ?$ & 2 & 3 & & 23 \\
\hline & $!$ & Aegopinella minor (Stabile, 1864) & & & & & 2 & 4 & 4 & 38 & 70 \\
\hline & (G) & Cochlodina cerata (Rossmässler, 1836) & & & $2 ?$ & 1 & $3 ?$ & $4 ?$ & 16 & 85 & 109 \\
\hline & $(!)$ & Fruticicola fruticum (O.F. Müller, 1774) & & & & & 1 & 1 & 3 & 11 & 5 \\
\hline & $!$ & Helix pomatia Linné, 1758 & & & $1 ?$ & & $1 ?$ & 2 & 5 & 17 & 20 \\
\hline & $(+)$ & Vitrea crystallina (O.F. Müller, 1774) & & & 1 & & & & & & \\
\hline \multirow[t]{2}{*}{3} & (G) & Clausilia pumila C. Pfeiffer, 1828 & & & & & & & 3 & 2 & 1 \\
\hline & (G) & Monachoides vicinus (Rossmässler, 1842) & & & & & & 1 & 1 & 2 & 1 \\
\hline \multirow{8}{*}{4} & $(+)$ & Granaria frumentum (Draparnaud, 1801) & & & & & 2 & 3 & 2 & 4 & 4 \\
\hline & + & Helicopsis striata (O.F. Müller, 1774) & & & 1 & & & & & & \\
\hline & $(+)$ & Chondrula tridens (O.F. Müller, 1774) & & & & & 2 & 4 & 11 & 4 & 16 \\
\hline & $(\mathrm{G})$ & cf. Chondrina clienta (Westerlund, 1883) & & & & 1 & & & & & \\
\hline & (G) & Pyramidula pusilla (Vallot, 1801) & & & & & & 2 & 2 & & \\
\hline & M & Oxychilus inopinatus (Uličný, 1887) & & & & & & 3 & 4 & 19 & 11 \\
\hline & $! !$ & Cepaea vindobonensis (A. Férussac, 1821) & & & & & & 1 & 2 & 7 & 6 \\
\hline & $! !$ & Truncatellina claustralis (Gredler, 1856) & & & & & & & 4 & 6 & 10 \\
\hline \multirow{4}{*}{5} & + & Pupilla muscorum (Linné, 1758) & & & & & 1 & & & & \\
\hline & $(!)$ & Truncatellina cylindrica (A. Férussac, 1807) & & & & 1 & 1 & & 3 & 15 & 49 \\
\hline & $(+)$ & Vallonia costata (O.F. Müller, 1774) & & & & & & & 3 & & \\
\hline & $\mathrm{G}$ & Vallonia pulchella (O.F. Müller, 1774) & & & & & & & 2 & 2 & 13 \\
\hline 6 & $(!)$ & Cochlicopa lubricella (Rossmässler, 1835) & & & & & 1 & & & 1 & 6 \\
\hline & $(!)$ & Euomphalia strigella (Draparnaud, 1801) & & & & 2 & 2 & 5 & 5 & 17 & 12 \\
\hline & $(+)$ & Euconulus fulvus (O.F. Müller, 1774) & & & 1 & & & & & 2 & 5 \\
\hline & $(+)$ & Limacidae / Agriolimacidae & & & & 1 & 1 & 1 & 8 & 57 & 43 \\
\hline & $(+)$ & Perpolita hammonis (Ström, 1765) & & & & & & & 1 & & \\
\hline 7 & $(+)$ & Punctum pygmaeum (Draparnaud, 1801) & & & & & & & 2 & 5 & 1 \\
\hline & $!$ & Vitrea contracta (Westerlund, 1871) & & & & & & & 3 & 17 & 4 \\
\hline & $(+)$ & Clausilia dubia Draparnaud, 1805 & 1 & 10 & 10 & 17 & 24 & 61 & 182 & 82 & 12 \\
\hline & $!$ & Laciniaria plicata (Draparnaud, 1801) & & & & & & & & 4 & \\
\hline & $(+)$ & Orcula dolium (Draparnaud, 1801) & & & & & & 5 & 11 & & \\
\hline & $(+)$ & Radix cf. ovata (Draparnaud, 1805) & & & & & & & & & 2 \\
\hline 10 & (G) & Bythinella austriaca agg. (von Frauenfeld, 1857) & & & & & & & & & 1 \\
\hline & & Unionidae & & & & & & & & 1 & 1 \\
\hline & er of Species & & 2 & 1 & 7 & 9 & 16 & 21 & 31 & 35 & 33 \\
\hline & ef of Individuals & & 2 & 10 & 16 & 25 & 47 & 108 & 302 & 462 & 490 \\
\hline
\end{tabular}


characterized by their occurrence, became established comparatively late in the course of the postglacial Climatic Optimum, being immediately prior to the occupation of the site by humans of the Kyjatice Culture at the turn of the Bronze and Iron Ages (800-400 BC). It should be stressed that even the richest woodland assemblages in layers 2 and 1 are associated with open-ground xerothermophiles such as Truncatellina claustralis, Cepaea vindobonensis, Oxychilus inopinatus as well as Granaria and Chondrula, which document the uninterrupted persistence of steppe patches throughout the whole succession.

In local context, the occurrence of the following taxa is particularly noteworthy:

- Discus rotundatus, a west mid-European element entered the eastern West Carpathians during the Climatic Optimum, but declined with the deterioration of climate in the Late Holocene.

- Truncatellina claustralis, Cepaea vindobonensis and Oxychilus inopinatus have appeared in the area of West Carpathian foothills since Neolithic times, which correspond to the Atlantic Period.

- The continuous occurrence of Chondrula and Granaria documents that in the surroundings of the cave, patches of primeval karst steppes still existed that have been mostly transformed to pastureland since the Neolithic landnam, which hindered the overall forestation of the landscape during the later phase of the Climatic Optimum.

\section{Local malacozones}

Mollusc abundances vary greatly throughout the sequence, so that a subdivision into local molluscan zones (MZ) is rather subjective and a mollusc diagram plotting the faunal data as percentages would be misleading. The results of the molluscan analyses are therefore presented only as numbers of individuals in Table 1 .

The lowermost part of the cave fill (layers 13-9) is virtually barren or includes only a few undeterminable small fragments. Consequently, the succession starts only in horizons 8-7 with a species-poor assemblage - MZ 1 entirely dominated Clausilia dubia, a cold-tolerant, prevailingly rupestral species that survived the glacial in mid-European uplands, where it continues to live at present. In the high limestone Carpathians and Alps, it is widespread even in the alpine belt. The paucity of this malacozone was probably influenced by the fact that the horizons in question were probably deposited deeper in the cave where shells become increasingly scarce due to the gradual retreat of its entrance.

MZ 2 comprises the mollusc assemblages of layers 6-5 which are also dominated by Clausilia dubia; however, they also contain an increasing number of catholic and particularly xerophilous species (Pupilla muscorum, Truncatellina cylindrica, Euomphalia strigella) as well as the first thermophilous taxa such as Granaria frumentum, Chondrula tridens, including more demanding or open woodland parkland elements, for instance Aegopinella minor or Fruticicola fruticum that appear in layer 5. Nevertheless, characteristic species of closed woodland are lacking. Whereas the fauna of layer $6 \mathrm{ab}$ is cold-tolerant, the assemblage of layer 5 reflects a warming under relative dry conditions, which suggests the establishment of steppe parkland and open woodland. This development is indicative of the transition between glacial and warmclimate conditions.

MZ 3 - The onset of zone MZ 3 is characterized by a parkland fauna rather similar to that of layer 5, but richer in thermophilous elements of the ecogroup 2 such as Helix pomatia or Oxychilus glaber. Its base is defined by the first appearances of the xerothermophilous taxa Cepaea vindobonensis and Oxychilus inopinatus, which entered the region of mid-European uplands with the arrival of early Neolithic farmers (ca $5500 \mathrm{yr}$ BC). The overlying layers 3-1 are characterized by the rapid expansion of closed forest species that culminates in layer 2 immediately prior to the final Bronze Age occupation represented by the Kyjatice Culture, whose pottery occurs at the boundary of layers 2 and 1. However, the concurrent increase in a number of thermophilous open-ground species (Ch. tridens, $O$. inopinatus, C. vindobonensis, T. claustralis and T. cylindrica) suggests that the developing canopy remained reasonably open, which indicates the establishment of a high diversity karst parkland similar to that of the nearby Slovak Karst where xerothermic karst steppes and Carpathian woods form an intricate patchwork.

The molluscan record from the Vel'ká Drienčanská Cave thus extends back to the end of the Vistulian pleniglacial and continues up to the present, showing general agreement with the mid-European developmental pattern except for the continuous presence of open-ground taxa in important amounts.

\section{Vertebrate succession (Ján DAROLA)}

The vertebrate remains recovered from the mollusc samples are given in Table 2. Although the bones and teeth of small mammals occurred at very low frequencies, they include several taxa that are of major biostratigraphic importance. From the paleoenvironmental point of view, the records of Dicrostonyx and Ochotona are of prime importance, since they reflect a predominantly open landscape under severe climatic conditions, which corresponds to the malacological evidence. Microtus gregalis indicates similar conditions; however, it becomes extinct only with the onset of the woodland expansion (layer 4). Otherwise, the vertebrate succession shows general agreement with the development of the malacofauna.

\section{Chronology}

As shown by the preceding analyses, the investigated depositional sequence formed during the late Vistulian Pleniglacial-Holocene time-span. The lowermost fossiliferous strata do not contain sufficient datable material. Although no glacial index species were found, the absolute dominance of Clausilia dubia, a cold-tolerant species that has survived the Last Glacial in Central Europe, may indicate Pleniglacial conditions similar to those of the present subalpine belt of the limestone West Carpathians.

Clausilia dubia remains equally important in the overlying horizon $6 \mathrm{ab}$, however, being associated with some 
Table 2. List of vertebrates found in the Great Drienčanská Cave

\begin{tabular}{|c|c|c|c|c|c|c|c|}
\hline \multirow[t]{2}{*}{ Vertebrata } & \multicolumn{7}{|l|}{ Layers } \\
\hline & 7 & $6 \mathrm{~b}$ & $6 a$ & 5 & 4 & 3 & 2 \\
\hline Sorex cf. araneus & & & & & $1-2$ & & \\
\hline Chiroptera sp. & $1-2$ & & & & 1 & & \\
\hline Lepus sp. & & & & & 1 & & \\
\hline Ochotona cf. pusilla & 1 & 1 & $1-2$ & & $1-2$ & 1 & \\
\hline Apodemus (Sylvaemus) sp. & & & & & 1 & & 1 \\
\hline Cricetus $\mathrm{sp}$. & & & & & 1 & & \\
\hline Clethrionomys glareolus & & & & & 1 & 1 & 3 \\
\hline Arvicola sp. & & & & & & 1 & 1 \\
\hline Pitymys sp. & 1 & & & & & & 1 \\
\hline Microtus arvalis & $1 ?$ & & 1 & $1-2$ & $1-2$ & $2-3$ & 1 \\
\hline Microtus oeconomus & & & & & $1 ?$ & $1-2$ & \\
\hline Microtus gregalis & & $2-3$ & $1 ?$ & $3-4$ & $3-4$ & & \\
\hline Dicrostonyx sp. & & 1 & & & & & \\
\hline Carnivora (Mustelidae ?) & & & & & & & 1 \\
\hline Mustelidae sp. & & & & & 1 & & \\
\hline Ophidia? & & & & & & & 1 \\
\hline
\end{tabular}

tolerant catholic taxa and particularly with the glacial index mammals Dicrostonyx and Ochotona. Of similar importance is the record of Helicopsis striata in $6 \mathrm{a}$, a characteristic loess species that is a very rare fossil within this part of Carpathian foothills. Furthermore, in layer $6 \mathrm{~b}$ a single flint fragment was found. To summarise, all these lines of evidence indicate that horizon 6 may be Late Glacial in age.

In layer 5 the malacofauna becomes progressively enriched in species with higher temperature requirements. The appearance of Aegopinella minor, Fruticicola fruticum and probably also Helix pomatia signifies the establishment of open woodland, whereas Granaria frumentum and Chondrula tridens are indicative of warm steppe patches. Such development is characteristic of the Early Holocene (Preboreal, Boreal).

Throughout the group of beds 4-1 the malacofauna becomes progressively enriched in closed-forest elements (ecogroup 1) that culminate in layer 2 , but occur at considerably lower frequencies than those of ecogroup 2 which are less shadedemanding. However, also the taxa requiring open xeric conditions (Granaria, Chondrula, Cepaea vindobonensis, Oxychilus inopinatus and particularly the highly xerothermophilous Truncatellina claustralis) continue to be important, which documents that the woodland included a considerable number of open steppic patches. It is reasonable to suppose that this development was affected by prehistoric humans since the Neolithic landnam has been documented by the record of early Neolithic pottery deeper in the cave interior (Bükk Culture - BÁRTA 1963 in KLIMENT 2000). The most noteworthy malacological record within this group of strata is that of Cepaea vindobonensis and Oxychilus inopinatus, because these species are agerelated to the Neolithic occupation and thus mid-Atlantic in age. Truncatellina claustralis appears later - during the
Epiatlantic Period, Helicodonta obvoluta only in the late Epiatlantic, which well corresponds with its arrival at the decline of the Bronze Age near the Subboreal-Subatlantic boundary (position of the Kyjatice pottery). The thickness of the Late Holocene strata is rather reduced so that a more detailed subdivision of the uppermost part of the sequence is hardly possible.

\section{Conclusions}

The faunal successions at the Vel'ká Drienčanská Cave illustrate the interaction of site-specific and regional influences. Climatic conditions, vegetation and prehistoric settlement appear to be the main local controlling factors, determining whether the faunal assemblages are thermophilous or cold-tolerant, steppe or silvicolous. The major conclusions may be summarized as follows:

- The sequence of cave deposits ranging in date from final Vistulian pleniglacial to the present includes a faunal succession that is characteristic of this time-span and corresponds to the general developmental pattern within the area of mid-European uplands.

- This timing is supported by the archaeological evidence.

- The continuous occurrence of open-ground zoocoenoses may be considered site-specific.

- The open-ground species were an important faunal component even at the time of the Neolithic landnam and their later development might be supported by the activities of prehistoric humans (pasturing, forest clearing).

- They also continued to be important during the culmination of the closed-forest fauna and occurred in rather high frequencies up to the present.

- During the whole Postglacial the landscape was a karst parkland, consisting of a patchwork of open woods, scrublands, karst steppes and minor mesic forests. 


\section{Acknowledgements}

The research was supported by the Grant Agency of the Czech Republic, P504/10/0688.

\section{References}

BÁRTA J., 1963: Desat' rokov speleoarcheologickej činnosti Archeologického ústavu SAV. - Slovenský kras, 4: 87-97.

Kliment J. (ed.), 2000: Príroda Drienčanského krasu. - Štátna ochrana prírody Slovenskej republiky, Banská Bystrica, 280 pp.
LožEK V., 1964: Quartärmollusken der Tschechoslowakei. - Rozpravy Ústředního ústavu geologického, Vol. 31, ČSAV, Praha, $374 \mathrm{pp}$.

LožEK V., 2006: Last Glacial paleoenvironments of the West Carpathians in the light of fossil malacofauna. - SGV - Antropozoikum, 26: 73-84.

LoŽEK V. \& CíleK V., 2003: Holocene Facies Development in Mid-European Uplands. In: Kotarba A. (ed.): Holocene and Late Vistulian Paleohydrology. Prace Geograficzne, 189: 255285. 